\title{
Ranching motivations in 2 Colorado Counties
}

\author{
HELEN IVY ROWE, E.T. BARTLETT, AND LOUIS E. SWANSON, JR.
}

Authors are research assistant and professor, Department of Rangeland Ecosystem Science and Chair and professor, Department of Sociology, Colorado State University, Fort Collins, Colo. 80523.

\begin{abstract}
The objectives of this Colorado study were to assess primary reasons ranchers choose to stay or sell the ranch, compare the motivations for ranching between a traditional agriculturally based county and a rapidly developing county, and assess whether factors such as length of tenure, fiscal dependency on ranching, and dependency on public lands play roles in decisions to sell. Personal interviews were conducted with 37 ranchers. While land use conversion occurs for a wide variety of reasons, lack of heirs and detrimental public policy were important reasons given for selling ranches. Responses showed Routt County (a rapidly developing county) ranchers were more likely to sell due to land use conversion related issues than Moffat County ranchers $(p=0.056)$. Ranchers with a longer legacy on their land reported that profitability, having likely heirs, and continuing tradition enhanced their reasons to stay. Groups more "at risk" of selling were non-homesteading ranchers close to retirement, larger ranches, and ranchers dependent on ranching for income with declining profits. Large ranch owners experiencing land use conflicts with non-ranchers and ranchers modestly dependent on public forage experiencing changes in public policy regulations and land use conflicts also indicated a higher proclivity to sell. Noting how groups of ranchers are impacted by different changes can help refine community efforts related to land use conversion and create more thoughtful policy measures.
\end{abstract}

Key Words: rangeland policy, regulations, survey, public lands, urban development, land use conversion

Colorado farm and ranch land has declined by over 600,000 ha since 1987 with over 80,000 ha lost to development and other uses in 1996 alone (Colo. Dept. of Agr. 1998). Land use conversion from agriculture to development results not only in a loss of agricultural production, but also fragments and degrades wildlife habitat and reduces open space. The current political climate advocates the conservation of ranches to protect against fragmentation and support open space, agriculture, and ecological integrity (Liffman et al. 2000). By asking ranchers why they stay or leave, we discover the underlying causes of land use conversion to better inform policy makers.

\section{Motivations to continue ranching}

Past research has indicated that factors other than profit or economic incentives influence decisions that shape a ranch family's decisions to stay on the land. Researchers have found that family,

\footnotetext{
Manuscript accepted 20 Oct. 2000.
}

\section{Resumen}

Los objetivos, bajo este estudio en el estado de Colorado, fueron: a) determinar las razones más importantes de los productores agrícolas para continuar con su unidad de producción o venderla, b) comparar las aspiraciones de producción entre una agricultura tradicional regional y una agricultura especializada, y c) determinar si factores como el tiempo de posesión, grávamen fiscal y el uso de terrenos comunales son decisivos para vender las unidades de producción. El método de estudio fue por entrevistas personales realizándose 37 con productores agrícolas. Las razones más importantes para la venta de la unidades de producción incluyen el cambio en el uso de la tierra, la falta de herederos y una política pobre sobre el uso de terrenos comunales. Los resultados mostraron que los productores especializados del Condado Routt fueron más propensos a la venta de las propiedades que los tradicionales del Condado Moffat $(P=.056)$. Los productores agrícolas con muchos años en la explotación reportaron que las ganancias, la existencia de herederos, y la tradición incrementa las razones para continuar produciendo. Los grupos propensos para vender fueron productores próximos al retiro, productores grandes en la escala, y productores con ganancias descendentes. Además, fueron propensos de venta los propietarios grandes con conflictos con otro tipo de productores y con productores agrícolas modestos dependientes de los cambios en la regulación de terrenos comunales para producción de forraje, y por conflictos con el uso de terrenos comunales. El factor más influyente en el ámbito de los productores agrícolas es el impacto de cambios diversos que pueden ayudar a afinar los esfuerzos comunitarios relacionados con cambios de uso de la tierra y con la creación de políticas de desarrollo más eficientes.

tradition, way of life, rancher image, and place attachment all motivate ranchers to retain ownership (Smith and Martin 1972, Harper and Eastman 1980, Grigsby 1980, Bartlett et al. 1989, Gentner 1999, Liffman et al. 2000). Selling the ranch itself is a market transaction, but the land may represent a way of life, livelihood, and family legacy, making the decision to sell difficult.

Previous studies indicate that for some ranchers, financial management tends to be a primary factor shaping a decision to stay in ranching. Smith and Martin (1972) identify a group characterized by their conspicuous consumption and speculative attitudes. Such individuals buy ranches as an investment and plan to sell for a higher price. These investors enjoy the "rancher image" and lifestyle, often as absentee landowners, until land values rise and reach a threshold that triggers a decision to sell. One group of 4 defined by Bartlett et al. (1989) expressed a willingness to sell the ranch, but remained due to "difficulties in selling in current market conditions." This group rated land ethic and family life 
slightly lower than the other groups. For this group it appears that economic considerations weigh more heavily in the sell or stay question. Young and Shumway (1991) support these findings, suggesting that factors including dependency on ranch income, desire to increase net worth, the perception of cattle production as a business venture, and the ability to obtain off-ranch employment all increased the probability that ranchers would perceive themselves to be profit maximizers. For these kinds of ranchers, the business tends to be a determining factor in decisions over the fate of the ranch.

\section{Motivations to sell a ranch}

Land use conversion issues, specifically, the "impermanence syndrome" and loss of "critical mass", appear related to decisions to sell or continue in ranching (Heimlich and Anderson 1987, Huntsinger and Hopkinson 1996, Hart 1991, Berry and Plaut 1978). Urbanization can lead to an "impermanence syndrome" among ranchers. This results in declining investment in agriculture and reduction in intensity of management and practices because ranchers become convinced that their land will be sold for non-agricultural uses (Heimlich and Anderson 1987). Speculation leads to idling farmlands or a conversion to other types of agriculture that are less intensive in time and capital (Berry and Plaut 1978, Conklin and Lesher 1977). Hart (1991) found that as urbanization increased around a ranch, succeeding generations were more likely to sell.

Once a ranching community loses its "critical mass" of ranchers, ranching may become less economically viable (Huntsinger and Hopkinson 1996, Hart 1991, Heimlich and Anderson 1987, Berry and Plaut 1978). As the numbers of agriculturalists declines, their political and economic clout erodes and non-farm preferences for community gain political legitimacy in local governance. New ordinances are passed designed to regulate such things as noise of machinery and tractors on roads. Demand for requisite suburban infrastructures by new residents can increase the tax load for ranchers (Berry and Plaut 1978, Lisansky and Clark 1987). Fewer ranchers in an area makes it more difficult to pool labor and resources at times of heavy work (Huntsinger and Hopkinson 1996). Furthermore, commercial businesses that provide agricultural supplies and services are more likely to go out of business as their ranching clients disappear (Flora et al. 1992, Danbom 1995, Starrs 1998).
Hart (1991, p. 35), in perhaps an overstatement to make a point, stresses the impact of urbanization on agriculture: "Urban expansion always wins, because farmers are not able to pay urban costs for land. The basic question of land conversion is not whether, but when."

\section{Hypotheses}

In the course of this research, several assumptions concerning ranchers' reasons to either stay in or leave ranching were considered. This paper addresses 5 alternative hypotheses.

1. Raising a family and maintaining tradition are primary determinants for staying in ranching.

2. Due to greater development pressure, ranchers in an area undergoing rapid development will be more likely to sell than those in a more rural, agricultural area.

3. Respondents with a longer legacy on the land will be less likely to sell.

4. Financial issues will be more important to larger ranches and for those dependent on ranch income for their livelihood.

5. Federal public land and environmental policies will affect public land dependent ranchers more than ranchers with less public land.

\section{Methods}

Thirty-seven (37) personal interviews with public land ranchers in the Colorado counties of Routt and Moffat were conducted. Ranchers were randomly selected from a compiled list of all of the federal land grazing permittees of the 2 counties.

\section{Study area}

To evaluate the effects of urbanization we compare 2 counties, one experiencing rapid development, Routt County, and the other a traditional agricultural county, Moffat County. Adjacent counties in the northwestern corner of Colorado, these 2 counties were selected for study based upon their relative proximity and similar cultural history, while differing in their growth rates and level of development. Routt County comprises 60,000 ha and $49 \%$ of its land is either state or federally owned. Moffat has 1.2 million ha with $63 \%$ of that in public ownership (Frank 1997). In 1992, Routt County had $3.4 \%$ income dependence on agribusiness, and
Moffat had 1.5\% (CSU Dept. of Agr. and Res. Econ. 1995).

Recreationists flock to Routt County for outdoor pursuits including skiing at the popular Steamboat Springs Ski Resort. The tourism industry in Routt County supports 147 related establishments for lodging, amusement/recreation, and eating/drinking. Moffat County has only 37 such businesses. Population growth in Routt has been double that in Moffat. Routt County had a growth rate of $18.3 \%$ between 1990 and 1997, while Moffat County increased by 8.9\% (Yampa Valley Partners 1999). The overall cost of living has also risen disproportionately for the 2 counties according to a cost of living survey in Colorado. This survey composed a numeric scale using 1 as the average for the state based on the costs for 59 goods. Routt County ranks highest in the "above average" category at 1.096, whereas Moffat falls into the "low" cost of living category at .870 (Garner and Eckert 1999). Property values in Routt County have leapt from $\$ 291.2$ million in 1993 to $\$ 419.2$ million in 1997 . For the same years, Moffat County crept from $\$ 358.7$ million to $\$ 367$ million (Yampa Valley Partners 1999). These county differences allow us to compare the effects of growth between rapidly developing Routt County and traditional Moffat County.

\section{Study Sample}

A sampling frame of 242 Federal permittees in the 2 counties was derived by compiling the Bureau of Land Management (BLM) and United States Forest Service (USFS) permittee lists and condensing duplicate listings. The sample size of 26 was calculated using a variance of .15 taken from Redmond et al. (1992), a study relevant to the research presented here. The sample was stratified into 7 strata based on number of AUMs and type of livestock grazed on public land, increasing the sample size. Every effort was made to interview each of these ranchers, but replacements were selected for those that refused, were not actively running their ranch, or who lived too far outside the counties. Thirty-seven personal interviews were completed.

\section{Rancher Survey}

Drawing on questionnaires of Liffman et al. (2000), Gentner (1999), Smith and Martin (1972), and Bartlett et al. (1989), the authors constructed a survey exploring motivations for staying in ranching versus leaving ranching. The survey was pre-tested on ranchers in Larimer County, Colo.

The questionnaire consisted of 7 general 
conceptual questions with 9 follow up questions. The general questions covered the following categories of information: quality of life, dependency on ranching for income, motivating factors for continuing to ranch, factors influential in selling the ranch, motives for staying in the area, and public policy issues. Most questions were measured on a Likert scale with 1 indicating least important, 2 less important, 3 moderately important, 4 more important, and 5 most important. The authors chose to group the Likert scale responses into either more important (4 and 5 answers) and less important $(1,2$, and 3$)$ to simplify the comparisons. Follow up questions were asked if the rancher responded with a 4 or a 5 to any of the questions in the motivations to sell category.

The Federal Policy Impacts Section of the questionnaire provided the independent variables to test hypotheses 3 through 5 , including the number of animal unit months (AUMs) and private land acres, the degree of public land dependency, and whether or not the rancher's family homesteaded in that county. Since 2 ranchers did not respond to the Federal Policy Impacts Section, only 35 survey results were used to test hypotheses 3 through 5 .

For Hypothesis One, simple frequencies showed which factors ranchers chose as most important for staying or leaving ranching. Hypotheses 2 through 5 required the use of the Chi-square statistic using cross tabs. Due to difficulty in finding significant differences with the small sample size and the minimal consequences of making a type I error, we considered differences of $p<0.10$ to be significant.

\section{Defining Groups}

To cross tab the groupings, continuous data was categorized for each hypothesis including homesteading history, county, dependence on ranching for income, size of ranch by private acreage, size of ranch by number of AUMs, and dependence on public lands. Ranches were re-categorized under each group (Table 1). Private land acreages and AUMs were divided along obvious splits in the data. Public land dependency was determined by dividing the number of public land AUMs by the total number of AUMs, multiplied by a hundred. Because public land dependency had an even spread, we split it into quartiles and defined these groups as negligible, modest, moderate and high public land dependency. Homesteading and dependency on ranching for income elicited yes/no responses in the survey and were categorized as such.
The sample included a number of ranchers that had public land in 1 of the counties, but they resided either in the other county or nearby across the Wyoming border. To refine the comparison, only Routt County residents were considered in the Routt County category. Any rancher not residing in Routt was placed in the Moffat County category (Table 1 ).

\section{Results and Discussion}

\section{Hypothesis One: Motivations for staying in ranching}

This research partly supported the first hypothesis. Family and tradition influences came out as important for over $50 \%$ of the sample. However, way of life outranked family and tradition as reasons to continue ranching. The data also reveal that attachment to the location of the ranch influences ranchers to stay in agriculture. Profit ranked lower as a motivational factor.

Ranchers report that they stay in ranching primarily because they enjoy the work and way of life (Table 2). Over 50\% of the respondents rated family and traditional reasons as most important. Family and tradition categories include: "A ranch is a good place to raise your family", consistency with family tradition, culture and values, living closer to family, "ranching is part of our Western heritage and should be preserved", "ranch has been in the family for generations and you maintain it to carry on the family tradition", and to have a business to pass on to your children (Table 2).

Table 1. Ranch characteristics, Routt and Moffat Counties, Colo., 1998.

\begin{tabular}{lc}
\hline \hline Characteristics $^{1}$ & with characteristic \\
\hline & $(\%)$ \\
Dependent on ranching for livelihood & 57 \\
Homesteaded & 58 \\
Rate quality of life great-excellent & 87 \\
Ranch in Routt County & 24 \\
Ranch in Moffat County & 76 \\
Small ranch: owns up to 1000 acres private land & 37 \\
Medium ranch: owns 1280-8000 acres private land & 43 \\
Large ranch: own 15,000-80,000 acres private land & 20 \\
Small ranch: $90-707$ total AUMs $/$ year & 40 \\
Medium ranch: $1068-8264$ total AUMs/year & 46 \\
Large ranch: 14,604-39,412 total AUMs/year & 14 \\
Negligible public land dependency: 1-11\% & 23 \\
Modest public land dependency: 14-34\% & 26 \\
Moderate public land dependency: 35-62\% & 26 \\
High public land dependency: 69-96\% & 26 \\
Not all ranchers answered each category; thus, n varied from 35-37. & \\
20tal AUMs includes federal, private, and privately leased forage, but does not include hay fed.
\end{tabular}

${ }^{\mathrm{T}}$ Not all ranchers answered each category; thus, $\mathrm{n}$ varied from 35-37.

${ }^{2}$ Total AUMs includes federal, private, and privately leased forage, but does not include hay fed.

In addition to asking about motivations to continue ranching, we asked why ranchers stayed where they are rather than selling the ranch to buy another one elsewhere. Responses to this were grouped in 11 categories. The top answers for both counties combined (with 36 responses) indicated that tradition (50\%) and attachment to the ranch setting $(39 \%)$ are both important reasons to continue ranching in the area. The response "tradition" means the rancher stays here because the ranch has been in the family for 1 or more generations. "Place attachment", as defined by the survey responses, encompasses love for life style and for the natural beauty of the area as well as simply not wanting to leave. Ranchers develop a connection to their ranch, the landscape, associated wildlife, and the beauty of the area. The Likert Scale responses support this enthusiasm for place attachment; $87 \%$ of the ranchers rated living near natural beauty as more important.

\section{Reasons for selling the ranch}

The corollary to the first hypothesis, that deteriorating the quality of raising a family or altering traditions would motivate ranchers to sell, is reflected in the responses (Table 2). Ranchers say that having no one to take over the ranch would be the most compelling reason to sell the ranch (57\%). Having no one to take over the ranch incorporates both loss of family and tradition, since with no one to inherit the ranch by definition indicates a severing with family tradition. Of the 21 respondents that marked this factor as more/most important, $13(62 \%)$ responded that it is 
Table 2. More important reasons to keep ranching or to sell responses listed in decreasing proportions, all respondents, 1999.

\begin{tabular}{|c|c|c|}
\hline Survey Questions $(\mathrm{n}=37)$ & Responded 4/5 & $\mathrm{n}$ \\
\hline You continue to ranch because: & $(\%)$ & \\
\hline You enjoy animal husbandry & 97 & 37 \\
\hline You enjoy the ranching way of life & 95 & 37 \\
\hline You like ranch work & 89 & 34 \\
\hline A ranch is a good place to raise your family & 87 & 37 \\
\hline Allows you to live near natural beauty & 87 & 36 \\
\hline Ranching allows you independence & 87 & 37 \\
\hline Owning land and a ranch is consistent with your family's traditions, culture and values & 81 & 37 \\
\hline Living on a ranch allows you to live closer to your family & 81 & 37 \\
\hline Ranching is part of our Western heritage and should be preserved & 76 & 37 \\
\hline The ranch has been in the family for generations and you maintain it to carry on the family tradition. & 57 & 37 \\
\hline You continue ranching so you will have a business to pass on to your children & 50 & 36 \\
\hline It would be difficult to obtain a job outside the ranch & 27 & 37 \\
\hline You own land and a ranch primarily for environmental purposes & 25 & 36 \\
\hline Living on a ranch allows you to live closer to your friends & 22 & 36 \\
\hline Profit & 19 & 37 \\
\hline Conservation easements or land trusts made the property taxes and my debt more manageable. & 18 & 28 \\
\hline Other & 32 & 12 \\
\hline \multicolumn{3}{|l|}{ You would sell the ranch because: } \\
\hline You have no one to pass the ranch on to & 57 & 37 \\
\hline Public policy regulations. & 49 & 37 \\
\hline You don't like the way the community is changing. & 32 & 37 \\
\hline Ranching is no longer profitable, you start losing money & 32 & 37 \\
\hline Increase in property value. & 30 & 37 \\
\hline Land use conflicts with non ranchers & 30 & 36 \\
\hline Nearby ranches being converted to other uses. & 22 & 37 \\
\hline Retirement & 11 & 36 \\
\hline Prefer to improve income through selling the ranch. & 11 & 37 \\
\hline Perception that society no longer appreciates ranching & 5 & 37 \\
\hline Prefer to improve income through an off-ranch job & 0 & 36 \\
\hline Other & 30 & 11 \\
\hline \multicolumn{3}{|l|}{ Why do you choose to stay here rather than sell the ranch and buy another one elsewhere? } \\
\hline Ranch has been in the family for one or more generations & 49 & 37 \\
\hline Place attachment & 38 & \\
\hline Moving does not solve problems in ranching & 19 & 37 \\
\hline Good place to ranch & 19 & 37 \\
\hline
\end{tabular}

${ }^{\mathrm{T}}$ For this open-ended question, percentages refer to response frequencies for each category.

more/most likely that a family member will take over for them in the future. Seven $(33 \%)$ thought it would be moderate to very unlikely that a family member would take over and $1(5 \%)$ did not know if it would be taken over by a family member. Thus, roughly $19 \%(7 / 37)$ of the sample will likely sell the ranch because they lack viable heirs.

Of particular significance to policy makers, public policy regulations were cited as the second most important reason to sell (18 respondents or $49 \%$ of the sample marked more/most important). This question clearly implied federal not local policies. The follow-up question asked these 18 respondents which policies most concerned them. Answers were categorized into 10 groups. The most frequent response was cuts in allowed grazing use on public lands (35\%). Some of the fear of cuts is probably rooted in the BLM environmental impact reports being done on all allotments at the time of the interviews in summer 1999. Thirty percent of the 18 respondents indicated concern about government control over land use, usually range improvements, on both public and private lands. Twenty percent cited multiple-use as a threat. These respondents feel that recreationists and hunters would restrict their own ability to use the public lands by creating problems (trespass, vandalism, etc) and demanding more of the public land exclusively for themselves. Though not evoked in the open-ended follow-up question, the Endangered Species Act (ESA) also seems to be a concern to ranchers. Each respondent ranked a set of 5 issues according to which would most likely affect his or her ranch in the next 5 years. The ESA outranked the other issues, followed by elk management, water quality, multiple use, and water rights. Rancher comments revealed a negative undercurrent towards the ESA. Ironically these Federal policies may serve to accelerate ranch sales, creating an even greater threat to policy goals aimed at slowing land use conversion and preserving wildlife habitat.

Eleven people provided other reasons for why they would sell the ranch. Seven indicated that a loss of health would cause them to sell the ranch. Other answers were aging, county regulations, and loss of family.

\section{Hypothesis 2: Routt County versus Moffat County}

Ranchers in Routt County were more likely to sell their ranches due to land con- 
Table 3. More important reasons for ranching or selling, Moffat versus Routt Counties, 1999.

\begin{tabular}{|c|c|c|c|}
\hline \multirow[t]{2}{*}{ Survey questions } & \multicolumn{2}{|c|}{ County } & \multirow[b]{2}{*}{ p-value ${ }^{1}$} \\
\hline & Moffat $(n=28)$ & Routt (n=9) & \\
\hline Independent variables $^{2}$ : & $(\%)$ & $(\%)$ & \\
\hline Did your family homestead in the area? & 44 & 63 & .329 \\
\hline Do you depend on ranching for your income? & 64 & 33 & .103 \\
\hline \multicolumn{4}{|l|}{ You continue to ranch because: } \\
\hline $\begin{array}{l}\text { Owning land and a ranch is consistent with your } \\
\text { family's traditions, culture and values }\end{array}$ & 75 & 100 & $.096^{*}$ \\
\hline Living on a ranch allows you to live closer to your family & 75 & 100 & $.096 *$ \\
\hline It would be difficult to obtain a job outside the ranch & 36 & 0 & $.036 * *$ \\
\hline Profit & 25 & 0 & $.096^{*}$ \\
\hline $\begin{array}{l}\text { Conservation easements or land trusts made the } \\
\text { property taxes and my debt more manageable }\end{array}$ & 10 & 43 & $.046^{* *}$ \\
\hline \multicolumn{4}{|l|}{ You would sell the ranch because: } \\
\hline If you had no one to pass the ranch on to & 54 & 67 & .49 \\
\hline Public policy regulations & 50 & 44 & .772 \\
\hline You don't like the way the community is changing & 29 & 44 & .376 \\
\hline Ranching is no longer profitable, you start losing money & 39 & 11 & .116 \\
\hline Land use conflicts with non ranchers & 36 & 11 & .16 \\
\hline Increase in property value & 32 & 22 & .571 \\
\hline Nearby ranches being converted to other uses & 14 & 44 & $.056^{*}$ \\
\hline \multicolumn{4}{|l|}{$\begin{array}{l}\text { Why do you choose to stay here rather than sell } \\
\text { the ranch and buy another one elsewhere? }\end{array}$} \\
\hline Been in the family for one or more generations & 54 & 33 & .145 \\
\hline Place attachment & 36 & 44 & .783 \\
\hline Moving does not solve problems in ranching & 11 & 44 & $.029 * *$ \\
\hline Good place to ranch & 22 & 11 & .466 \\
\hline
\end{tabular}

version issues than in Moffat County (Table 3). Routt County residents ranked "Nearby ranches being converted to other uses" the second most common reason to sell. This marked a significant difference with Moffat, which marked this factor as seventh. Land use conversion influencing ranchers to sell supports the large body of literature indicating that urbanization causes ranchers to sell because of a lessening expectation of the persistence of agriculture as a viable use in an area, and the loss of "critical mass" (Huntsinger and Hopkinson 1996, Hart 1991, Heimlich and Anderson 1987, Berry and Plaut 1978, Conklin and Lesher 1977).

Also worthy of note were the reactions to easements and land trusts in the 2 counties. Although rated low in both counties, significantly more people rated these as important reasons to continue ranching in Routt County than in Moffat County (Table 3). Generally, only the people holding land trusts themselves considered easements important. This result is perhaps not surprising considering land trusts are more common in Routt County. Locally based conservation policies appear to have a positive influence on ranchers' willingness to keep their land from being developed. counties (Table 4). Significantly more ranchers in Routt than in Moffat County feel that ranch difficulties may exist on any ranch, therefore moving will not resolve the problem. This finding may reveal that Routt County ranchers perceive their profession as more inherently plagued with difficulty than do their more traditional Moffat County neighbors.

Comparing the reasons ranchers continue may reveal interesting sets of characteristics for each county. Routt County ranchers focus more on the family, and less on profit (Table 3). Moffat County ranchers seem to care more about profit and are less concerned about family as a reason to ranch.

\section{Hypothesis 3: Legacy on the Land}

We hypothesized that respondents with a longer legacy on the land would be less likely to sell. Respondents with a longer legacy on the land were defined as homesteaders; their family had originally homesteaded in the area. To support this hypothesis, homesteaders would have marked fewer sell factors as more/most important and more reasons to continue as more/most important. In general this was not strongly supported by the data. However, homesteaders considered themselves less likely to sell the ranch at retirement (Table 4). Relative newcomers to ranching may view the ranch as more of a profession from which to retire rather than a way of life that continues into retirement.

Homesteaders place more importance on economics, as measured by profit and dif-

Table 4. More important reasons for homesteaders to sell or continue ranching, Routt and Moffat Counties, 1999.

\begin{tabular}{|c|c|c|c|}
\hline Survey questions & $\begin{array}{l}\text { Homesteaders } \\
\quad(\mathrm{n}=21)\end{array}$ & $\begin{array}{l}\text { Non-homesteaders } \\
(\mathrm{n}=15)\end{array}$ & p-value ${ }^{1}$ \\
\hline You continue to ranch because: & $(\%)$ & $(\%)$ & \\
\hline $\begin{array}{l}\text { You continue ranching so you will have a } \\
\text { business to pass on to your children }\end{array}$ & 65 & 33 & $.064 *$ \\
\hline $\begin{array}{l}\text { Living on a ranch allows you to live closer } \\
\text { to your family }\end{array}$ & 67 & 100 & $.013 * *$ \\
\hline $\begin{array}{l}\text { It would be difficult to obtain a job } \\
\text { outside the ranch }\end{array}$ & 38 & 7 & $.032 * *$ \\
\hline Profit & 29 & 0 & $.023 * *$ \\
\hline $\begin{array}{l}\text { The ranch has been in the family for } \\
\text { generations and you maintain it to } \\
\text { carry on the family tradition }\end{array}$ & 81 & 20 & $.000 * * *$ \\
\hline You would sell the ranch because: & & & \\
\hline Retirement & 0 & 27 & $.014 * *$ \\
\hline$\underline{\text { Independent variable }}^{2}$ & & & \\
\hline $\begin{array}{l}\text { Do you depend on ranching for } \\
\text { your income? }\end{array}$ & 62 & 47 & $.364 * *$ \\
\hline
\end{tabular}


Table 5. Significant correlations between independent variables using Pearson's r-values.

\begin{tabular}{|c|c|c|c|c|}
\hline & \multicolumn{4}{|c|}{ Independent variables } \\
\hline & County & $\begin{array}{l}\text { Dependency on ranching } \\
\text { for income }\end{array}$ & Homesteading & $\begin{array}{c}\text { Size (number of } \\
\text { AUMs) }\end{array}$ \\
\hline Public land dependency & & & $-.325 *^{3}$ & \\
\hline $\begin{array}{l}\text { Size of ranch } \\
\text { (by number of AUMs) }\end{array}$ & $.349 * *^{2}$ & $-.430 * * *^{3}$ & & \\
\hline $\begin{array}{l}\text { Size of ranch } \\
\text { (by number of acres } \\
\text { of private land) }\end{array}$ & $.485^{* * * 2} *^{2}$ & $-.504 * * *^{3}$ & & $.700 * * * 4$ \\
\hline
\end{tabular}

$*, * *, * * *$ Significant at the $0.10,0.05$ and 0.01 levels respectively.

${ }^{1}$ Homesteaders have a higher dependency on public land than non-homesteaders.

${ }^{2}$ Rancher in Routt County had fewer AUMs and owned less private land than ranchers in Moffat County.

${ }^{3}$ Larger ranches, as defined both by number of AUMs and number of private acres, are more dependent on ranching for their livelihood.

${ }^{4}$ Ranches with large number of AUMs also held higher acreages of private land.

ficulty in finding a job off the ranch, as reasons to stay than do the more recent non-homesteaders (Table 4). Perhaps homesteaders ingrained in their successors the paradigm of the ranch as a business that needs to support the family needs. Members of older ranching families may have less outside work experience or professional training which keeps them tied to the ranch. Newcomers to the trade may have more job options and financial resources, allowing them to be somewhat more economically sacrificial in their attitudes towards ranching. They know they are giving up a higher standard of living for ranching and perhaps are more resigned to being "satisficers" (Smith and Martin 1972).

Not surprisingly, homesteaders also find passing the ranch on to children and maintaining tradition as reasons to stay (Table 4). Taken together, given a profit and willing heirs, homesteaders may feel more strongly about staying in ranching than their counterparts.

\section{Hypothesis 4: Financial Concerns}

The results tend to support the assumption that owners of larger ranches and ranchers more dependent on ranching for their income are more concerned with profit. Ranches with more AUMs, more private land, and ranchers who declared themselves dependent on ranching for their income (3 highly correlated variables, Table 5) stated that they would be much more likely to sell if the ranch started losing money than their counterparts (Table 6). This same set of ranchers agrees that difficulty in obtaining a job off of the ranch contributes to their reasons to continue ranching. Ranchers dependent on ranching also cited profit as a significantly more important reason to continue ranching than non-dependent ranchers.

Another finding, with strong implications for land use conversion policy, was that as size of ranch increases, land use conflicts with non-ranchers become a greater motivation to sell (Table 6). As land around large ranches is converted to non-ranching uses, resulting conflicts may influence larger ranch owners to sell.

\section{Hypothesis 5: Public Lands Ranchers}

Ranchers more highly dependent on public lands for forage did not show significantly more likelihood to sell due to public policy than those with lower dependency. It turns out, however, that it is the modestly (14-34\% of their total forage is from public land) dependent ranchers who are likely to sell due to public policy regulations and land use conflicts (Table 7). This occurrence may be explained by seasonal dependence. Ranchers in the modestly dependent category have enough dependency to be affected by changes but may have fewer options in the face of such changes. These ranchers may depend on public forage for a specific period of time when no other forage is available whereas larger landholders may have more flexibility. Another possibility is that ranchers in the modestly dependent category are selfselected (i.e., their fear of being harmed by policy changes has already led them to reduce their public land).

It stands to reason that public land dependent ranchers, many of whom are homesteaders, would place more value on tradition as a reason to continue on the ranch. The data shows a correlation between homesteaders and increased dependency on public lands (Table 5). Further, public land dependent ranchers

Table 6. More important reasons to sell reported by ranches of different sizes and income dependencies, Routt and Moffat Counties, 1999.

\begin{tabular}{|c|c|c|c|c|c|c|c|c|c|c|c|}
\hline \multirow[t]{2}{*}{ Survey questions } & \multicolumn{4}{|c|}{$\mathrm{AUM}^{1}$} & \multicolumn{3}{|c|}{ Dependency $^{3}$} & \multicolumn{3}{|c|}{ Acreage $^{4}$} & \multirow[b]{2}{*}{$\mathrm{p}$} \\
\hline & Small & Medium & Large & $\mathrm{p}^{2}$ & Low & High & $\mathrm{p}$ & Small & Medium & Large & \\
\hline You continue to ranch because: & $(\%)$ & $(\%)$ & $(\%)$ & & $(\%)$ & $(\%)$ & & $(\%)$ & $(\%)$ & $(\%)$ & \\
\hline $\begin{array}{l}\text { Ranching is no longer profitable, } \\
\text { you start losing money }\end{array}$ & 14 & 25 & 100 & $.001 * * *$ & 13 & 48 & $.024 * *$ & 15 & 20 & 86 & $.002 * * *$ \\
\hline $\begin{array}{l}\text { Perception that society no longer } \\
\text { appreciates ranching }\end{array}$ & 0 & 0 & 40 & $.002 * * *$ & $-^{5}$ & - & - & 0 & 0 & 29 & $.014 * *$ \\
\hline Land use conflicts with non-ranchers & 0 & 44 & 60 & $.007 * * *$ & - & - & - & 15 & 20 & 71 & $.019 * *$ \\
\hline Public policy regulations & 21 & 69 & 60 & $.030 * *$ & - & - & - & - & - & - & - \\
\hline \multicolumn{12}{|l|}{ You continue to ranch because: } \\
\hline $\begin{array}{l}\text { It would be difficult to obtain a } \\
\text { job outside the ranch }\end{array}$ & 21 & 19 & 80 & $.023 * *$ & 6 & 43 & $.013 * *$ & 8 & 33 & 57 & $.057 *$ \\
\hline You enjoy animal husbandry & 100 & 100 & 80 & $.062 *$ & - & - & - & - & - & - & - \\
\hline Allows you to live near natural beauty & - & - & - & - & - & - & - & 100 & 73 & 100 & $.049 * *$ \\
\hline Profit & - & - & - & - & 19 & 29 & $.086^{*}$ & - & - & - & - \\
\hline
\end{tabular}

*'**, *** Significant at the $0.10,0.05$ and 0.01 levels respectively

${ }^{1}$ Size of ranch categorized by the total number of AUMs, not including hay feed.

$2 \mathrm{p}$-value of given category for $x^{2}$ test.

${ }^{3}$ Level of dependency on ranch income for their livelihood as defined by respondents.

${ }_{5}^{4}$ Size of ranch categorized by the number of owned private acres on the ranch.

${ }^{5}$ Non-significant values not included in this table. 
Table 7. More important reasons to stay or sell the ranch at different levels of dependence on public forage, Routt and Moffat Counties, 1999.

\begin{tabular}{|c|c|c|c|c|c|}
\hline \multirow[b]{2}{*}{ Survey questions } & \multicolumn{4}{|c|}{ Levels of public land dependency } & \multirow[b]{2}{*}{$\mathrm{p}$-value } \\
\hline & Negligible & Modest & Moderate & High & \\
\hline \multicolumn{6}{|l|}{ You continue to ranch because: } \\
\hline $\begin{array}{l}\text { Owning land and a ranch is consistent with } \\
\text { your family's traditions, culture and values }\end{array}$ & 50 & 89 & 100 & 78 & $.065^{*}$ \\
\hline $\begin{array}{l}\text { The ranch has been in the family for } \\
\text { generations and you maintain it to carry } \\
\text { on the family tradition }\end{array}$ & 0 & 67 & 89 & 67 & $.002 * *$ \\
\hline $\begin{array}{l}\text { Ranching is part of our Western } \\
\text { heritage and should be preserved }\end{array}$ & 50 & 67 & 100 & 89 & $.064 *$ \\
\hline \multicolumn{6}{|l|}{ You would sell the ranch because: } \\
\hline Land use conflicts with non-ranchers & 0 & 56 & 22 & 33 & $.083 *$ \\
\hline Public policy regulations & 25 & 89 & 44 & 33 & $.036 * *$ \\
\hline
\end{tabular}

rate tradition as an important factor for staying on the ranch (Table 7).

\section{Conclusions}

Ranchers in northwestern Colorado emphasize career fulfillment, tradition, place attachment and family as reasons they intend to stay in agriculture. Profit and market factors rank relatively low as reasons to stay. Respondents list inheritance issues as the most important reason to sell, followed by public land policy regulations, economic issues, and community change. Age and loss of health may also be important reasons to sell.

Generally, this study did not find that rapid development alone would cause ranchers to sell, although land use conversion in developing counties might increase ranchers' likelihood of selling. Land use conversion can lead to conflicts with neighbors, a factor that large landowners indicated would influence them to sell. Homesteaders are less likely to sell the ranch at retirement, and profit and heirs to inherit the ranch tends to bolster their conviction to stay. Financial considerations are influential in decisions to continue in agriculture for respondents with larger ranches, dependence on ranching for an income, and with a higher dependence on public lands. Modestly dependent rather than highly dependent public land ranchers indicated an inclination to sell their ranch due to public policy regulations and conflict with non-ranchers.

This research presents a potential irony for policy makers who advocate strong environmental and other land-use programs on both public and private land. Given the finding that respondents rank changes in public policy as the second federal programs may inadvertently contribute to land use conversion by accelerating the rate of ranch sales.

The federal policies specified by ranchers as most pressing were cuts in grazing, government regulations concerning land use management, multiple use conflicts, and the Endangered Species Act (ESA). A recent study done in Routt County (American Farmland Trust 2000) described more subtle impacts that federal policies are having on ranchers' ability to continue ranching in the face of increasing land use conversion. This American Farmland Trust (2000) study found that tax incentives for buying a second home, allowing 35-acre subdivided parcels to continue to be taxed at agricultural land rates even given their weak ties to agriculture, and zoning laws that permit subdividing land into 35-acre or greater parcels without a review process hastens land use conversion from agriculture into residential properties. Federal and local policies supporting conservation easements help sustain commercial ranching but could be strengthened. The American Farmland Trust study (2000) emphasizes that policies designed to protect public lands increase development pressure on private ranchlands by luring more recreationists to the area, while also limiting the potential supply of land for development. Moreover, cutting grazing rights or substantially increasing grazing fees "will almost certainly mean additional pressure to subdivide and convert working ranches into recreational properties" (American Farmland Trust 2000, p. 14). The findings of this study in combination with the results found here should alert policy makers to the potential vulnerability of ranchers to an array of federal policies, both overt and indirect. most important reason for selling a ranch,
Decisions ranchers make about selling their ranch directly affect the use of their land and can contribute to land use conversion into subdivisions or other developments. Conversely, if ranchers do not sell their land, land use conversion is slowed. Diminished quality of ranch life, public policy regulations, the inability to pass the ranch on to future generations, land use conversion and its associated conflicts, and, for some groups, loss of profitability, may induce ranchers to sell.

\section{Literature Cited}

American Farmland Trust. 2000. The last roundup? How public policies facilitate rural sprawl and the decline of ranching in Colorado's Mountain valleys, a summary report, $19 \mathrm{p}$.

Bartlett, E. T., R. G. Taylor, J. McLean and J. G. Hof. 1989. Motivations of Colorado ranchers with federal grazing allotments. J. Range Manage. 42:454-457.

Berry, D. and T. Plaut. 1978. Retaining agricultural activities under urban pressure: a review of land use conflicts and policies. Policy Sci. 9:153-178.

Colorado Department of Agriculture. 1998. Colorado Agricultural Statistics Service Report 1996-1997. Denver, Colo.

Colorado State University (CSU), Department of Agricultural and Resource Economics. 1995. Colorado's farm and food system: its contribution to the state economy in 1992. Colorado State University Cooperative Extension Resource Center, executive summary of bulletin \#551A. Fort Collins, Colo.

Conklin, H. E. and W. G. Lesher. 1977. Farm-value assessment as a means for reducing premature and excessive agricultural disinvestments in urban fringes. Amer. J. Agr. Econ. 59(4):755-759.

Danbom, D. B. 1995. Born in the country: a history of rural America. Johns Hopkins University Press, Baltimore, Md.

Flora, C. B., Jan L. Flora, Jacqueline D. Spears, Louis E. Swanson, Mark B. Lapping and Mark L. Weinberg. 1992. Rural communities legacy and change. Westview Press, Boulder, San Francisco, and Oxford.

Frank, T. 1997. Colorado land ownership summary by county (acres) table. Colorado Department of Agriculture, Resource Analysis Section.

Garner, E. H. and J. B. Eckert. 1999. Cost of living differences in Colorado: a summary of county-level estimates for 1998. Dept. of Agr. Econ., Colorado State University Cooperative Extension.

http://www.colostate.edu/Depts/CoopExt/PU BS/CONSUMER/xcm211.html.

Gentner, B. 1999. Characteristics of public land grazing permittees. Masters Thesis. Dept. of Agr. and Res. Econ., Oregon State Univ., Corvalis, Ore. 
Grigsby, T. L. 1980. Today's riders of the purple sage: symbols, values, and the cowboy myth. Rangelands 2:93-96.

Harper, W.M and C. Eastman. 1980. An evaluation of goal hierarchies for small farm operators. Amer. J. Agr. Econ. 62:742-747.

Hart, J. F. 1991. Farming on the edge: saving family farms in Marin County, California. Univ of Calif. Press, Berkeley, Calif.

Heimlich, R. E. and W. D. Anderson. 1987. Dynamics of land use change in urbanizing areas: experience in the Economic Research Service, 135-154. In: William Lockeretz (ed.), Sustaining Agriculture Near Cities. Soil and Water Cons. Serv., Washington D.C.

Huntsinger, L. and P. Hopkinson. 1996. Viewpoint: sustaining rangeland landscapes: a social and ecological process. J. Range Manage. 49:167-173
Liffman, R. H., L. Huntsinger and L. C. Forero. 2000. To ranch or not to ranch: home on the urban range? J. Range Manage. 53:362-370.

Lisansky, J. and G. Clark. 1987. Farmer-nonfarmer conflicts in the urban fringe: will right-to-farm help? p. 219-230. In: William Lockeretz (ed.), Sustaining Agriculture Near Cities. Soil and Water Cons. Serv., Washington D.C.

Redmond, J. T., E. T. Bartlett, P. Gutierrez and V. G. Carande. 1992. Costs of grazing on federal lands and private leases: a 1991 Colorado comparison. Dept of Rangeland Ecosystem. Sci., Colorado State Univ. Coop. Exten., 28 p.

Smith, A. J. and W. E. Martin. 1972. Socioeconomic behavior of cattle ranchers with implications for rural community development in the West. Amer. J. Agr. Econ. 54:217-225.
Starrs, P. 1998. Let the cowboy ride: cattle ranching in the American West. Johns Hopkins University Press, Baltimore, Md.

Yampa Valley Partners. 1999. Yampa Valley Partners community indicators project, 1999 report, 1. Colorado Healthy Communities Initiative. Craig, Colo.

Young, K. D. and C. R. Shumway. 1991. Cow-calf producers' perceived profit maximization objective: a logit analysis. So. J. Agr. Econ. 23:129-36.

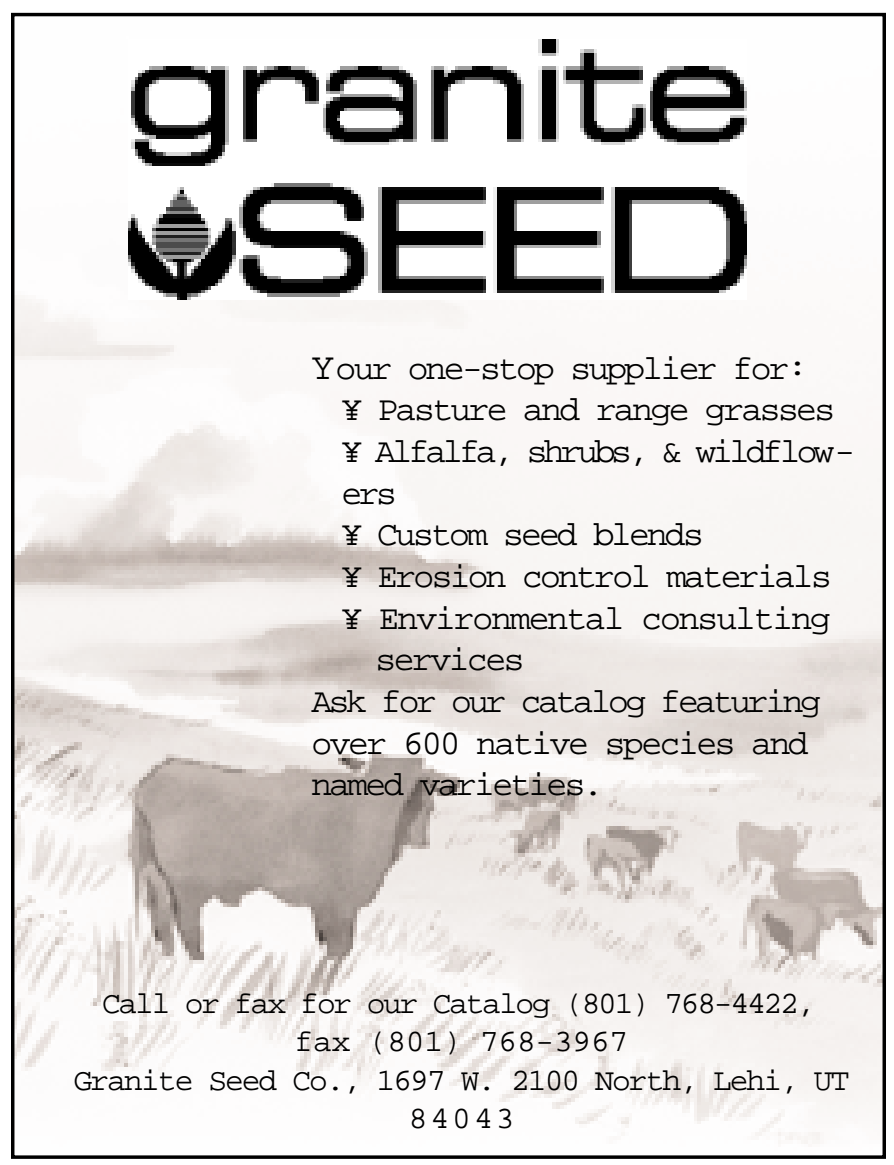

